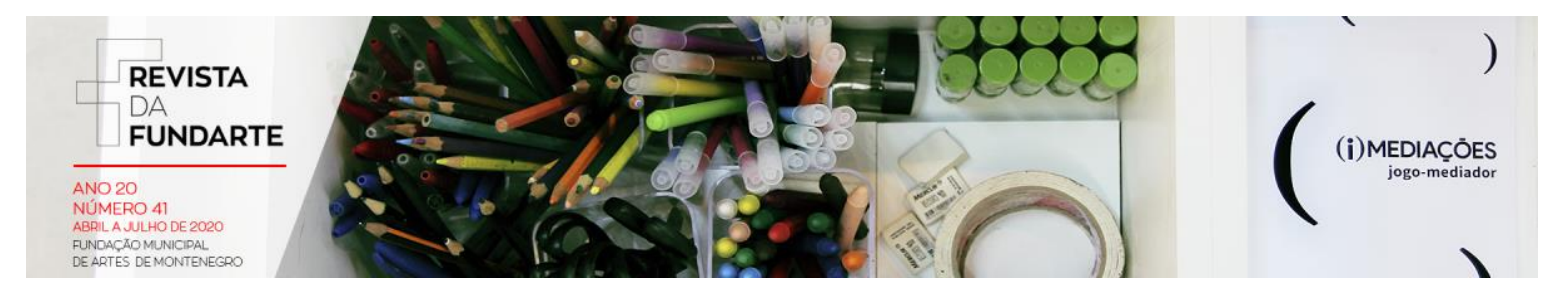

\title{
RELEXÕES SOBRE O CONCEITO DE BELO E SUBLIME ESTENDENDO-SE A ARTE CONTEMPORÂNEA
}

\author{
Julia Maria Hummes \\ Márcia Pessoa Dal Bello \\ Ubyrajara Brasil Dal Bello
}

DOI: http://dx.doi.org/10.19179/2F2319-0868.771 conceito de belo e sublime estendendo-se a arte contemporânea. Revista da FUNDARTE. Montenegro, p.01-21, ano 20, oㅡ 41, Abril/Junho de 2019.

Disponível em: http://.seer.fundarte.rs.gov.br/index.php/RevistadaFundarte/index> 30 de junho de 2020 


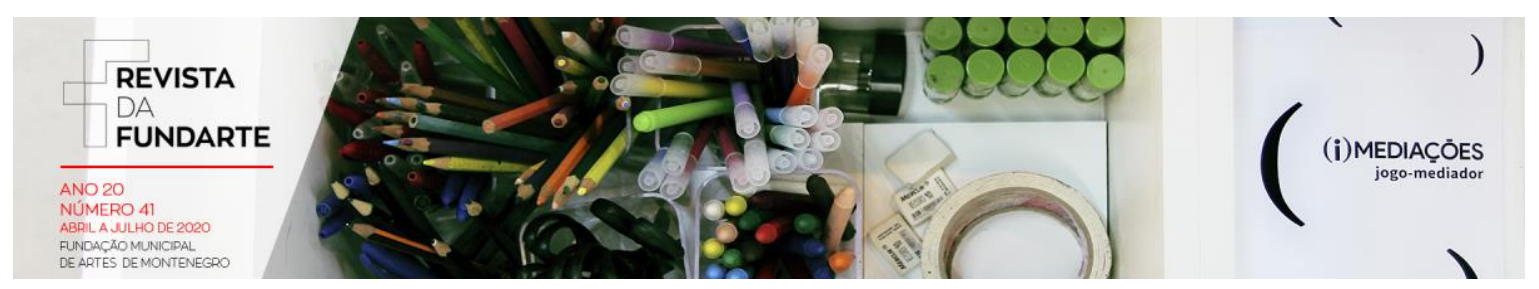

\title{
RELEXÕES SOBRE O CONCEITO DE BELO E SUBLIME ESTENDENDO-SE A ARTE CONTEMPORÂNEA
}

\author{
Julia Maria Hummes ${ }^{1}$ \\ Márcia Pessoa Dal Bello² \\ Ubyrajara Brasil Dal Bello ${ }^{3}$
}

Resumo: este artigo, de caráter ensaístico, não tem a intenção de trazer respostas, mas sim visa referendar alguns autores que trataram do tema do Belo e o Sublime. Num primeiro momento, traz o conceito de belo segundo a perspectiva de Emmanuel Kant (1978, 1993, 1995, 2005, 2006), cujo significado relaciona-se mais diretamente ao juízo do gosto, o qual é essencialmente subjetivo. Já o sublime, para Kant, está mais ligado aos conceitos objetivos de poder e de grandeza, embora conservando muitas características semelhantes ao belo. Esse autor procurou expressar o conceito de sublime por categorias, tais como: "sublime terrível", "sublime nobre" e "sublime magnífico", o que implica uma subjetividade ainda maior que o próprio belo, o qual está mais ligado às questões do "gostar" ou "não gostar". Num segundo momento, o texto apresenta o diálogo de alguns autores com Imanuel kant, acerca do tema do belo e o sublime, tais como: Deleuze (1963), Jimenez (1999), Schopenhauer (2003), Burke (2008), Eco (2014), de modo a expandir a reflexão sobre esses dois conceitos fundamentais no campo das artes. Finalizando, aponta para caminhos mais contemporâneos da Arte.

Palavras - Chave: Belo; Sublime; Kant.

\section{RELEXÕES ABOUT THE CONCEPT OF THE BEAUTIFUL AND SUBLIME}

\begin{abstract}
1 Mestrado em Educação Musical pelo PPGEMUS/UFRGS, Graduada no curso de Licenciatura Educação Artística, com habilitação em Música/UFRGS. Atualmente é Diretora Executiva da Fundação Municipal de Artes de Montenegro/FUNDARTE. Tem experiência na área de Educação Musical, atuando principalmente nos seguintes temas: teoria da música, apreciação musical e produção artística. É membro da Associação Brasileira de Editores Científicos - ABEC e EditoraChefe da Revista da FUNDARTE. É Delegada na Setorial de Música do Estado do Rio Grande do Sul.

2 Doutora em Educação pelo PPGEDU/FACED/UFRGS. Mestre em Educação pelo PPGEDU/UNISINOS. Especialista em Psicopedagogia/ULBRA. Graduada em Pedagogia, com Habilitação em Supervisão Escolar, pela Universidade Mackenzie/SP. É Pesquisadora e Coordenadora de Ensino na Fundação Municipal de Artes de Montenegro/FUNDARTE. É membro do Grupo de Pesquisa Estudos em Educação, Teatro e Performance-GETEPE/PPGEDU/FACED/POS; tem experiência na área de Educação, com ênfase em Métodos e Técnicas de Ensino, atuando principalmente nos seguintes temas: educação, arte, saberes pedagógicos e formação docente.

${ }^{3}$ Graduação em Direito pela Pontifícia Universidade Católica de São Paulo (1979), Graduação em Economia pela Universidade Presibiteriana Mackenzie (1981), MBA em Comércio Exterior pela FGV (1994) e Mestrado em Administração de Empresas pela Unisinos/ Pontifícia Universidade Católica do Rio de Janeiro (2000). Sua especialização concentra-se nas áreas de estratégia organizacional, marketing, comércio exterior e análise de projetos. Atualmente é professor concursado de Economia na Universidade Estadual do Rio Grande do Sul - Uergs.
\end{abstract}

HUMMES, Julia Maria; DAL BELLO, Márcia Pessoa; DAL BELLO, Ubyrajara. Relexões sobre o conceito de belo e sublime estendendo-se a arte contemporânea. Revista da FUNDARTE. Montenegro, p.01-21, ano 20, oㅜ 41, Abril/Junho de 2019.

Disponível em: http://.seer.fundarte.rs.gov.br/index.php/RevistadaFundarte/index> 30 de junho de 2020 


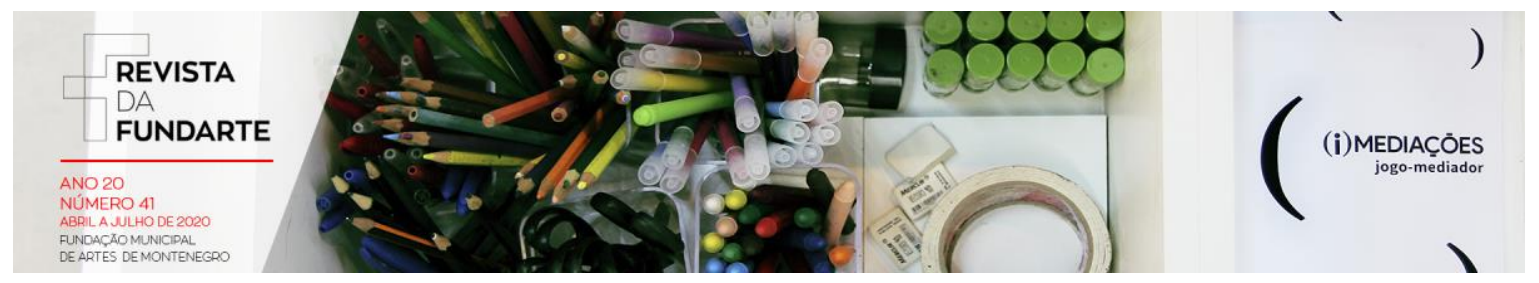

Abstract: This article aims, essayistic character, has no intention of bringing answers but rather aims to reference some authors who treated the topic the beautiful and the Sublime. At first, reflect on the concept of beautiful according to the perspective of Emmanuel Kant $(1978,1993,1995,2005,2006)$, whose meaning is related more directly to the senses of taste, which is essentially subjective. Already the sublime to Kant's more connected to the concepts of power and objectives of greatness, however, preserving many features similar to Nice. Kant sought to express the concept of sublime by categories, such as: "terrible", "sublime sublime noble" and "sublimely magnificent", which implies a subjectivity even bigger than his own beautiful, which is more linked to issues of "like" or "dislike". Secondly, this article seeks to confront the thinking of other authors that deal with the same theme, such as Deleuze (1963), Jimenez (1999), Schopenhauer (2003), Burke (2008), Eco (2014) in order to expand the reflection on these two concepts fundamental in the field of the arts. Finalizing points to more contemporary art paths.

Keywords: Nice; Sublime; Kant.

\section{CONSIDERAÇÕES INICIAIS}

"Belo e Sublime" são palavras intimamente vinculadas às artes, mais especificamente à estética e ao fenômeno artístico. $E$ as artes se vinculam profundamente com as emoções humanas, e os humanos têm necessidade de traduzir esses sentimentos em palavras e conceitos que lhes sejam inteligíveis. Logo, a origem etimológica de ambas vem do latim, sendo bellus para o belo e sublimis para o sublime.

Historicamente, portanto, a palavra belo é fruto da estética clássica, grega e romana, e diz diretamente respeito a determinadas características visíveis ao objeto de apreciação. Contudo, os gregos antigos não tinham uma definição clara sobre o que é beleza (talvez, nem nós tampouco), sendo o termo grego mais próximo para beleza ou belo, a palavra kalón. Eles associavam a beleza a outros valores como, por exemplo, a sabedoria e a justiça.

Assim, percebe-se que o belo grego era algo amplo, em que a estética em si e a ideia de valores se combinavam. Não obstante, para os gregos, o belo deveria responder a três critérios: ordem, simetria e proporção, ou seja, a valorização das medidas proporcionais na busca pela beleza ideal. Como não poderia ser diferente, aí está a lógica grega a julgar o que é ser belo.

HUMMES, Julia Maria; DAL BELLO, Márcia Pessoa; DAL BELLO, Ubyrajara. Relexões sobre o conceito de belo e sublime estendendo-se a arte contemporânea. Revista da FUNDARTE. Montenegro, p.01-21, ano 20, no 41, Abril/Junho de 2019.

Disponível em: http://.seer.fundarte.rs.gov.br/index.php/RevistadaFundarte/index> 30 de junho de 2020 


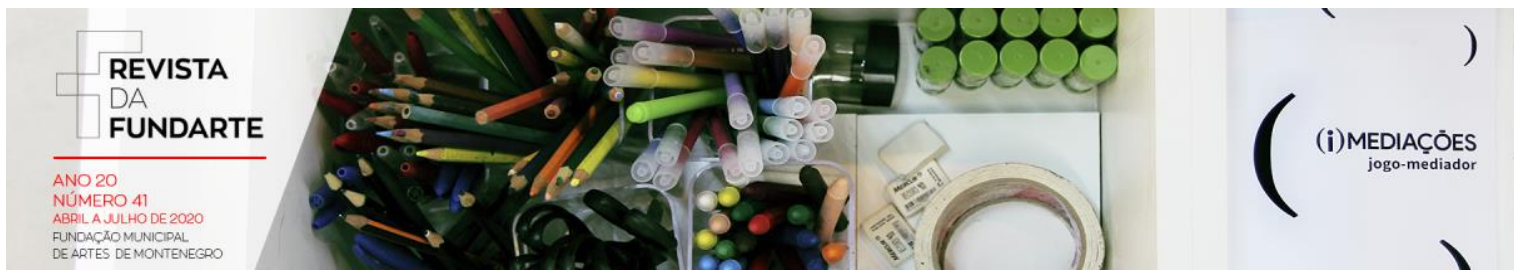

Seja como for, o belo passou a significar, com o passar do tempo algo que agrada, algo que suscita admiração. Assim, percebe-se que o belo grego era algo amplo, em que a estética em si e a ideia de valores se combinavam.

Mas a arte se transforma, a humanidade refinou-se e o guerreiro clássico cedeu seu espírito ao deleite do artístico. A expressão "belo" já não era suficiente para explicar o que ia à alma diante de uma obra artística. Daí dizer-se que no final do século XVIII, com o inaugurar do romantismo ${ }^{4}$, o uso do termo sublime torna-se mais frequente, cujo significado pode ser entendido como "aquele ou aquilo que se eleva" ou "aquele ou aquilo que se sustenta no ar". Sublime é, portanto, a condição estética que provoca o afloramento da sensibilidade. O sublime, na origem de seu emprego, tinha uma relação direta com a natureza, essa considerada misteriosa e extraordinária.

O termo foi inicialmente empregado na retórica e na poesia, passando a ter aceitação mais ampla após 1674, quando foi publicada a tradução francesa de Nicolas Boileau do "Tratado sobre o sublime", escrito em algum período entre os séculos I e III, por um anônimo (BELLAS, 2016).

Como conceito estético, o sublime comporta uma qualidade de larga amplitude, caracterizada por força subjacente que transcende o belo. $O$ sublime remete a quem o experimenta, a um sentimento de algo não acessível ante o incomensurável. Como resultado, provoca certo estranhamento, espanto, inspirado

\footnotetext{
${ }^{4} \mathrm{O}$ romantismo foi um movimento artístico, político, e filosófico surgido nas últimas décadas do século XVIII na Europa que durou por grande parte do século XIX. Caracterizou-se como uma visão de mundo contrária ao racionalismo e ao iluminismo e buscou um nacionalismo que viria a consolidar os estados nacionais na Europa. Inicialmente apenas uma atitude, um estado de espírito, o romantismo toma mais tarde a forma de um movimento, e o espírito romântico passa a designar toda uma visão de mundo centrada no indivíduo. Os autores românticos voltaram-se cada vez mais para si mesmos, retratando o drama humano, amores trágicos, ideais utópicos e desejos de escapismo. Se o século XVIII foi marcado pela objetividade, pelo iluminismo e pela razão, o início do século XIX seria marcado pelo lirismo, pela subjetividade, pela emoção e pelo eu. O termo romântico refere-se ao movimento estético, ou seja, à tendência idealista ou poética de alguém que carece de sentido objetivo. O romantismo é a arte do sonho e fantasia. Valoriza as forças criativas do indivíduo e da imaginação popular. Opõe-se à arte equilibrada dos clássicos e baseia-se na inspiração fugaz dos momentos fortes da vida subjetiva: na fé, no sonho, na paixão, na intuição, na saudade, no sentimento da natureza e na força das lendas nacionais (https://pt.wikipedia.org/wiki/Romantismo).
}

HUMMES, Julia Maria; DAL BELLO, Márcia Pessoa; DAL BELLO, Ubyrajara. Relexões sobre o conceito de belo e sublime estendendo-se a arte contemporânea. Revista da FUNDARTE. Montenegro, p.01-21, ano 20, no 41, Abril/Junho de 2019.

Disponível em: http://.seer.fundarte.rs.gov.br/index.php/RevistadaFundarte/index> 30 de junho de 2020 


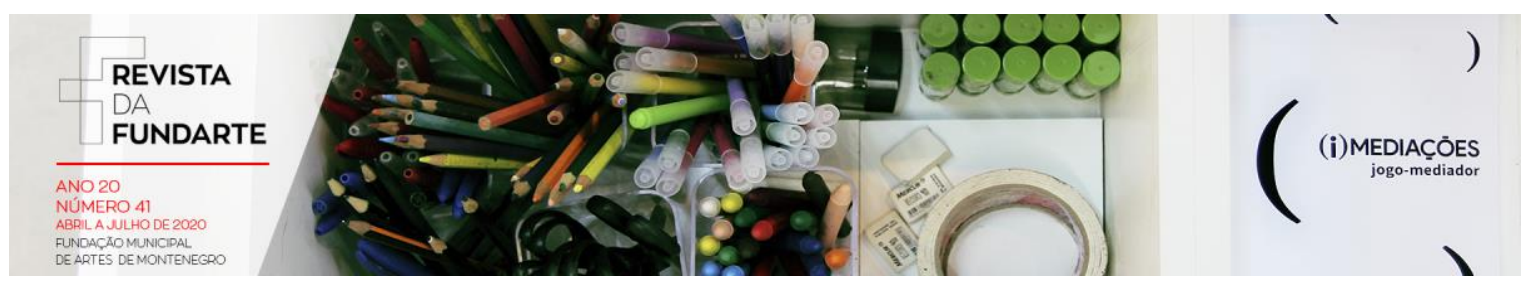

pelo medo ou pelo respeito. A qualidade do sentimento sublime consiste em ela ser a faculdade do ajuizamento estético, ou seja, um sentimento de desprazer pelo objeto, representado pelo fato de uma incapacidade própria de uma consciência ilimitada

O sublime está ligado ao sentimento de inacessibilidade diante do desmedido, do ilimitado, do descomunal. Um exemplo seria a dimensão de encantamento diante de um tornado ou de uma sinfonia de Mozart, os quais causariam uma emoção mais intensa do que aquela provocada pelo objeto, o qual se atribui o conceito de belo. $O$ gosto pelo sublime prevalece sobre o gosto pelo belo, uma vez que nasce da vontade de definir o indefinível.

Diante desse introito, cabe dizer que o presente artigo pretende refletir a respeito dos conceitos de belo e sublime, no sentido de repensá-los no contexto da arte, sem a intenção de fechar nenhum pensamento tido como verdade absoluta, mas de dialogar com alguns autores sobre conceitos tão próximos ao universo da arte. Dessa forma, para tal, a análise se fundamentará, principalmente, em Immanuel Kant e alguns pensadores que também se debruçaram sobre o tema,

\section{O BELO E O SUBLIME NA PERSPECTIVA DE KANT}

Kant escreveu três grandes obras relacionadas entre si e complementares: Crítica da Razão Pura (1781), Crítica da Razão Prática (1788) e Crítica da Faculdade de Juízo (1790).

$\mathrm{Na}$ sua primeira obra, Kant investigou a faculdade do conhecimento. Nesse livro, ele tenta responder a primeira das três questões fundamentais da filosofia: "Que podemos saber? Que devemos fazer? Que nos é lícito esperar?"

O autor distingue duas formas de saber: o conhecimento empírico, ou seja, aqueles relacionados às percepções dos sentidos, isto é, posteriores à experiência e o conhecimento puro, aquele que não depende dos sentidos, independente da experiência, ou seja, a priori, universal e necessário. Para Kant, o conhecimento 


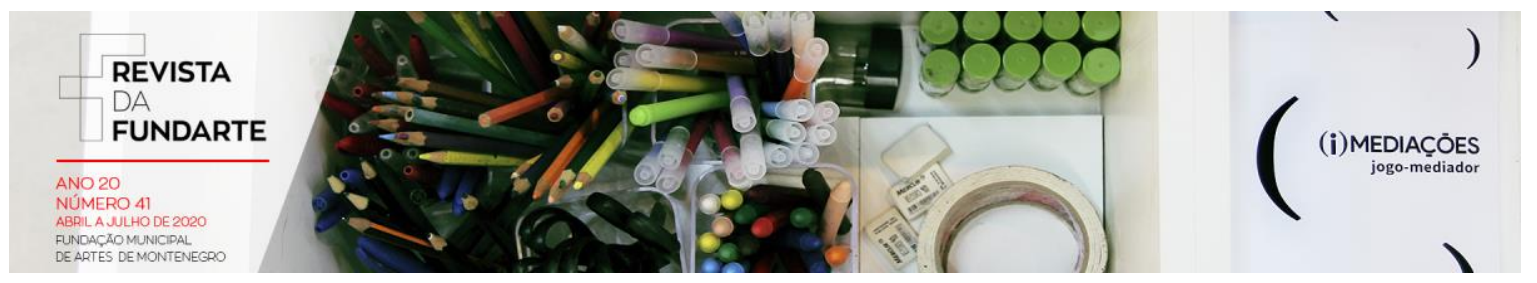

verdadeiro só é possível pela conjunção entre matéria, proveniente dos sentidos, e forma, que são as categorias do entendimento.

No seu segundo estudo, publicado em 1788, a Crítica da Razão Prática, Kant se volta para os princípios da moral. Nessa obra, ele analisa as condições de possibilidade para uma moral com pretensão universalista e apresenta, mais uma vez, o seu o imperativo categórico: forma da lei moral para uma vontade imperfeita. Cria, então, o famoso enunciado do imperativo categórico: aja de tal modo que a máxima da tua ação possa valer como lei universal. Esse imperativo é então tornado como condição necessária à razão para revelar a liberdade e autonomia da vontade.

$\mathrm{Na}$ terceira obra, a mais relevante para efeitos desse artigo, Kant investiga os limites daquilo que podemos conhecer pela nossa faculdade de julgar. Na verdade, ele vai além da razão: leva em consideração a memória e os sentimentos. $\mathrm{Na}$ primeira parte da Crítica da Faculdade de Juízo Estético, Kant analisa minuciosamente o belo por meio de quatro categorias: qualidade, quantidade, finalismo e modo. Igualmente analisa o sublime e introduz a noção de gênio. Não obstante o esforço hercúleo de Kant ao abordar o belo, o sublime, o gênio e inclusive, as Belas Artes, ele acabou não formulando uma teoria estética, já que o juízo estético é reflexionante, segundo o termo forjado pelo próprio filósofo e portanto, em última análise, subjetivo.

De acordo com Lino:

A Crítica da Faculdade do Juízo (1790) é concebida pelo próprio filósofo como mediadora entre as duas outras obras críticas. Na primeira destas, a Crítica da Razão Pura (1781), Kant debruçou-se na investigação acerca da faculdade do conhecimento (entendimento), já na seguinte, a Crítica da Razão Prática (1788), o interesse voltou-se para a faculdade de apetição (razão) e ao investigar como se dão os juízos nos sentimentos de prazer e desprazer na Crítica da Faculdade do Juízo é proposta, então, uma possibilidade de transitar entre as duas primeiras críticas, posto que a faculdade de julgar exerce um papel intermediário entre o entendimento e a razão. (LINO, 2008, p. 27).

HUMMES, Julia Maria; DAL BELLO, Márcia Pessoa; DAL BELLO, Ubyrajara. Relexões sobre o conceito de belo e sublime estendendo-se a arte contemporânea. Revista da FUNDARTE. Montenegro, p.01-21, ano 20, no 41, Abril/Junho de 2019.

Disponível em: http://.seer.fundarte.rs.gov.br/index.php/RevistadaFundarte/index> 30 de junho de 2020 


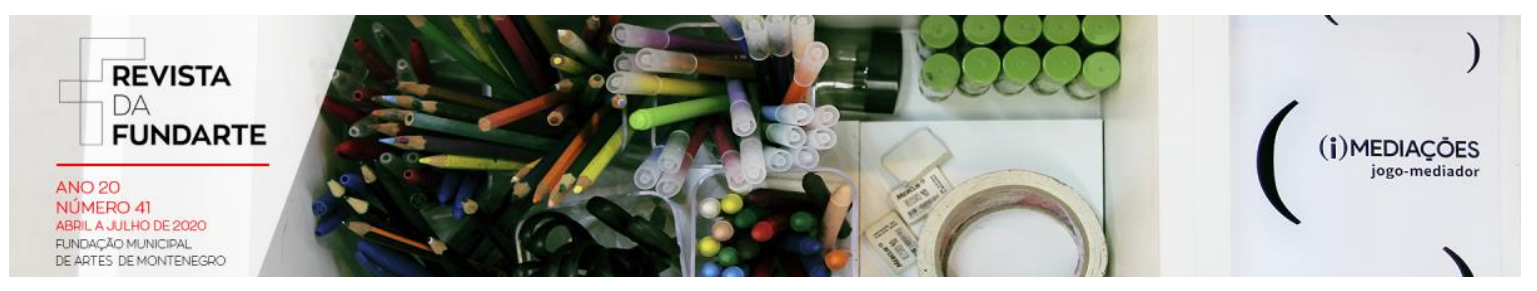

Para Kant, juízo significa a faculdade de conectar representações, de acoplar sujeito e predicado e, a partir dessas atrelagens, obter conhecimento. Para o filósofo, existem duas espécies de juízo: os juízos determinantes e os juízos reflexionantes. Os primeiros são juízos que formam o objeto. É um juízo de caráter essencialmente intelectual. Por meio dele, o objeto empírico é instituído, na medida em que o material da experiência é absorvido. Por exemplo, a constatação de que o calor é decorrência do objeto fogo. Por outro lado, quando o juízo já encontra um objeto previamente constituído, sem a necessidade de um esforço interpretativo ou relacional, resta-lhe apenas refletir sobre o objeto, para encontrar um meio de subordiná-lo a uma referência de ordem pessoal que lhe dê sentido.

O juízo estético, de caráter reflexionante, usa da faculdade da imaginação para conseguir o entendimento. $O$ juízo estético não se interessa pelo objeto em si, mas pelos potenciais efeitos que o objeto possa causar (ou efetivamente cause) ao humor do sujeito. Logo, o caráter desinteressado do juízo estético é determinado pelo modo como as faculdades de conhecimento do sujeito se comportam diante de certos objetos tidos como belos. Se o agradável proporciona concordância, ela é vinculada ao deleite. Assim, por gerar prazer diretamente nos sentidos, faz com que o sujeito não desvincule sua complacência da existência do objeto, pois o interesse por ele é imediato, devido ao prazer proporcionado por ele aos sentidos.

O fator determinante do belo é justamente o prazer desinteressado. Nas palavras de Kant: "Não se tem que simpatizar minimamente com a existência da coisa, mas ser a esse respeito completamente indiferente para em matéria de gosto desempenhar o papel de juiz" (KANT, 2005, p. 50).

Em resumo, a concepção kantiana na Crítica da Faculdade do Juízo determina que a expressão "belo" é originária do juízo de gosto. O juízo de gosto é, em sua essência, estético. Sendo assim, não implica conhecimento acerca apriorístico do objeto e está ligado ao sentimento de prazer e desprazer do sujeito diante do objeto ou de sua representação. Para que alguma coisa seja considerada bela, há de se utilizar a faculdade do gosto, a qual é fundamentalmente subjetiva. Se

HUMMES, Julia Maria; DAL BELLO, Márcia Pessoa; DAL BELLO, Ubyrajara. Relexões sobre o conceito de belo e sublime estendendo-se a arte contemporânea. Revista da FUNDARTE. Montenegro, p.01-21, ano 20, no 41, Abril/Junho de 2019.

Disponível em: http://.seer.fundarte.rs.gov.br/index.php/RevistadaFundarte/index> 30 de junho de 2020 


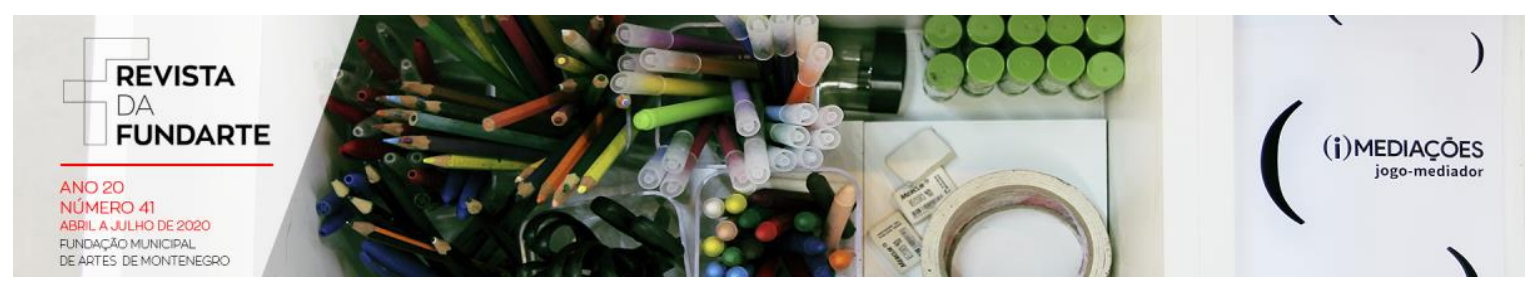

o fundamento para o belo é responsabilidade de quem elabora tal ou qual juízo, isso indica que não há determinação conceitual, consequentemente, não há construção de conhecimento sobre o objeto. A partir da formação do juízo sobre o belo, haverá prazer ou desprazer, e a consequência deste ou daquele sentimento terá como característica a inexistência de qualquer interesse.

Pode-se dizer que os sentimentos do belo e do sublime apresentam aspectos semelhantes, justamente, porque ambos provêm do juízo de reflexão. Tanto o belo quanto o sublime aprazem por si mesmos. São desinteressados. E são considerados juízos singulares, "contudo juízos que se anunciam como universalmente válidos com respeito a cada sujeito, se bem que na verdade reivindiquem simplesmente o sentimento de prazer e não o conhecimento do objeto" (KANT, 2005, p. 90).

A diferença entre tais sentimentos está na relação destes com o objeto contemplado. $O$ belo refere-se à apreensão da forma do objeto, enquanto o sublime pode ser encontrado no disforme. No caso do sentimento sublime, a natureza "em seu caos ou em suas mais selvagens e desregradas desordem e devastação suscita as ideias do sublime quando somente poder e grandeza podem ser vistos" (KANT, 2005, p. 91).

O sentimento do sublime diferencia-se do belo justamente por apresentar certa autonomia com relação à natureza. Tal sentimento é incitado por fenômenos naturais, mas fundamenta-se na capacidade racional do homem. Pelo fato de o sublime oferecer uma complacência comunicável universalmente, apresenta-se também nesse ajuizamento a consciência de uma conformidade subjetiva no uso da nossa faculdade de conhecimento (KANT, 2005, p. 95). Porém, no juízo do sublime, não há a representação de nenhuma forma particular na natureza, como ocorre no juízo sobre o belo.

Silva (2006) complementa afirmando que no sublime, o objeto pode aparecer como inadequado e violento para a faculdade da imaginação, entretanto para Kant, (2005) esta inconformidade da imaginação é a faculdade máxima da sensibilidade (KANT, 2005, p. 95). Ele considera que "se trata de um sentimento de inadequação da exposição da ideia do todo, entretanto é aí que a faculdade da imaginação atinge HUMMES, Julia Maria; DAL BELLO, Márcia Pessoa; DAL BELLO, Ubyrajara. Relexões sobre o conceito de belo e sublime estendendo-se a arte contemporânea. Revista da FUNDARTE. Montenegro, p.01-21, ano 20, o 41, Abril/Junho de 2019.

Disponível em: http://.seer.fundarte.rs.gov.br/index.php/RevistadaFundarte/index> 30 de junho de 2020 


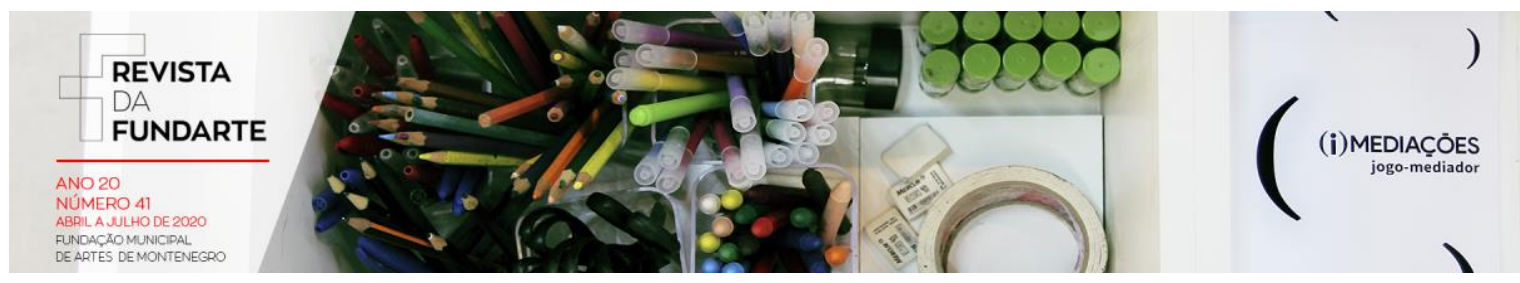

o seu máximo, e na ânsia de ampliá-lo pode recair, entretanto a experiência é transposta numa comovedora complacência" (KANT, 1978, p.98).

Kant distinguiu três modalidades: o sublime terrível que mistura a admiração da grandiosidade com o temor ou o horror (exemplo: um precipício imenso, a cratera de um vulcão a vomitar lava), o sublime nobre, em que a admiração da grandiosidade se mistura com a nobreza assente na simplicidade, (exemplo: uma catedral gótica, sem decorações interiores) e o sublime magnífico (exemplo: um palácio residencial recoberto a ouro e pedras preciosas). Escreveu:

\begin{abstract}
Os carvalhos altos e a sombra solitária no bosque sagrado são sublimes, as plantações de flores, sebes baixas, e árvores recortadas, formando figuras, são belos. A noite é sublime, o dia é belo. Os temperamentos que possuem o sentimento do sublime, quando a tremulante luz das estrelas rasga a parda sombra da noite e a lua solitária está no horizonte, são atraídos pouco a pouco pela calma silenciosa de uma noite de verão, as sensações supremas de amizade, de desprezo do mundo, de eternidade. O resplendor do dia infunde afãs de actividade e um sentimento de regozijo. $O$ sublime comove, o belo encanta. O semblante do homem que se encontra em pleno sentimento do sublime é sério, às vezes rígido e ensombrado. Pelo contrário, a viva sensação do belo declara-se no olhar pela sua esplendorosa serenidade, por sorrisos rasgados e por um claro regozijo. (KANT, 2008, p.32).
\end{abstract}

Sob a perspectiva do juízo estético, Kant considera que o belo traz em si a harmonia, pois provoca uma sensação de beleza universal. Para o autor, o sublime se instaura no espírito, e pressupõe a faculdade da imaginação e a subjetividade do indivíduo. Dessa maneira, para Kant, o belo provoca um sentimento de ternura e o sublime encanta. Dessa forma, para distinguir se algo é belo, em primeiro lugar, é preciso referir a representação do objeto, o qual se manifesta, não através do entendimento humano do objeto, mas por meio da faculdade da imaginação do sujeito.

Assim, é possível afirmar, a partir do pensamento Kantiano, que a diferença entre a noção de belo e de sublime se aproxima da ideia de que o belo se dá a partir da contemplação que o sujeito faz de um determinado objeto. $E$ através da contemplação, o sujeito é provocado a refletir acerca daquilo que está

HUMMES, Julia Maria; DAL BELLO, Márcia Pessoa; DAL BELLO, Ubyrajara. Relexões sobre o conceito de belo e sublime estendendo-se a arte contemporânea. Revista da FUNDARTE. Montenegro, p.01-21, ano 20, no 41, Abril/Junho de 2019.

Disponível em: http://.seer.fundarte.rs.gov.br/index.php/RevistadaFundarte/index> 30 de junho de 2020 


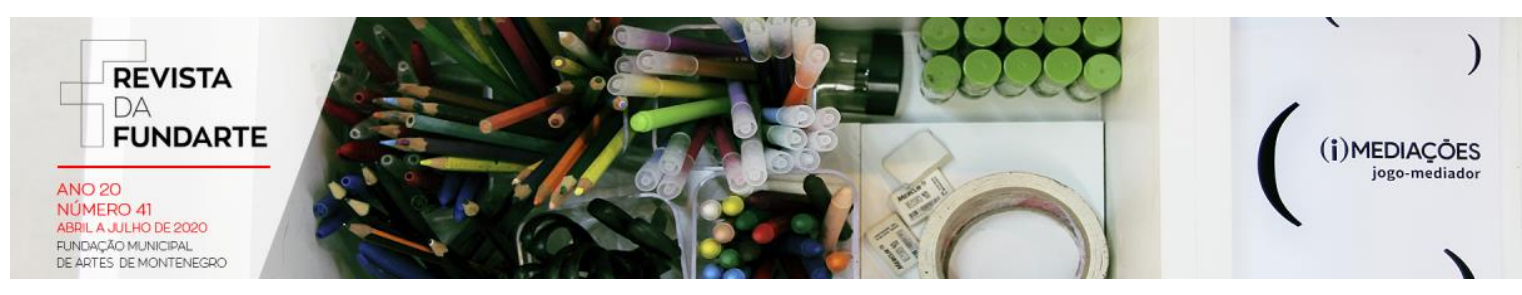

comtemplando. O sublime está ligado a grandeza, por isso não deve ser procurado nas coisas da natureza, mas no interior do espírito humano. Desse modo, o belo está em conformidade com o sublime, pelo fato de ser contemplação do objeto presente na natureza exterior e o sublime, é a grandeza do objeto que se manifesta na natureza interior do espírito humano.

\section{CONCEITOS DE BELO E SUBLIME: OUTROS OLHARES}

O sublime de Burke se opõe ao Belo. Para ele, o Belo está ligado a beleza, a lisura, a clareza de cores, a graça e elegância. Mas o Sublime implica em vastidão, terror, obscuridade, solidão, silêncio, ou seja, tudo aquilo que pode despertar a ideia de dor e perigo. Ao contrário do Sublime, o Belo de Burke é aquilo que produz prazer.

Para Burke, o sentimento sublime só pode se manifestar esteticamente se for derivado de tais sensações, a saber: a dor e o prazer. Tudo que seja de algum modo capaz de incitar as ideias de dor e de perigo, isto é, tudo que seja de alguma maneira terrível, ou que esteja relacionado a objetos terríveis. ou atua de algum modo análogo ao terror, constitui uma fonte do sublime. $O$ autor revela que o sublime "produz a mais forte emoção de que o espírito é capaz" (BURKE, 1993, p.48).

Ele argumenta que se o sentimento de sublime constitui a máxima capacidade de sentir do sujeito, esses objetos capazes de promover tal sentimento não são ou não deveriam ser fornecidos pela arte. Segundo Burke, essa sensação jamais poderia ser inspirada com o auxílio de objetos de arte, pois aqui o sentimento em questão passa por determinada espécie de filtro quando se relaciona com a arte. "Os objetos artísticos já denunciam a sua ligação direta com a ficção e isso acabaria por produzir o desaparecimento da possibilidade e da intensidade requeridas para esse tipo de sensação" (BURKE, 1993, p. 54). Por exemplo, como ocorre nas grandes desgraças reais e infortúnios, muitas vezes representados pela arte. 


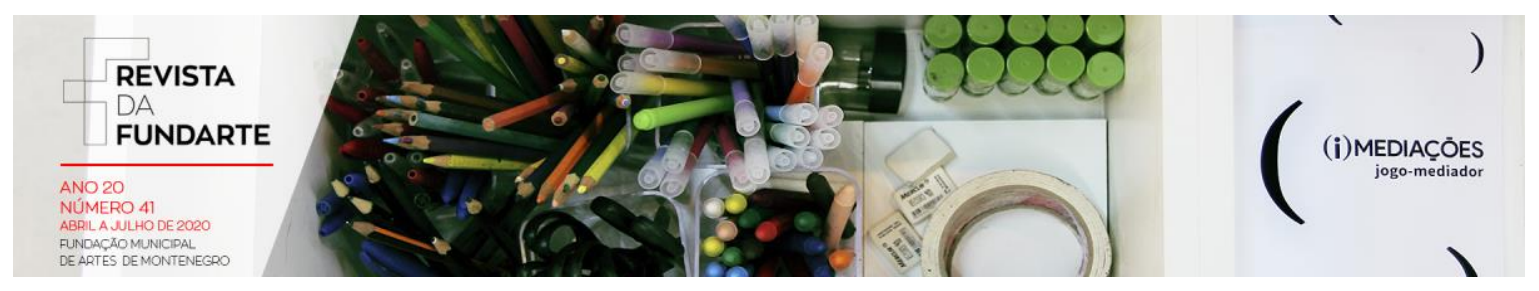

Já para Eco (2014), aquilo que é belo é definido pelo modo como nós o apreendemos, analisando a consciência daquele que pronuncia um juízo de gosto. Para o autor, "o Belo é algo que como tal se mostra para nós, que o percebemos, que está ligado aos sentidos, ao reconhecimento de um prazer, é ideia predominante em ambientes filosóficos diversos" (ECO, 2014, p. 275-277). O autor considera que o sublime é aquilo que produz a mais forte emoção que o espírito é capaz de sentir e, assim como o Belo, também predomina em ambientes filosóficos.

Schopenhauer (2008), outro pensador que buscou definir os conceitos de Belo e Sublime defende que no Belo o predomínio do conhecimento puro se exerce sem resistência. A beleza do objeto, sua constituição facilita por si só o conhecimento da ideia inerente à expressão do que se considera Belo. Portanto, é imperceptível à consciência, a qual persiste como sujeito do conhecimento, destituído, inclusive, de toda recordação da vontade.

Vontade, para Schopenhauer, é o único elemento permanente e invariável do espírito. É aquele que lhe dá coerência e unidade. Constitui a essência do homem. A vontade seria o princípio fundamental da natureza, independente da representação, não se submetendo à racionalidade e seus critérios. Logo, em contraposição, o Sublime, diferentemente do Belo, conquista o estado de conhecimento puro, primeiramente, por meio de uma libertação violenta das relações do objeto com a vontade. Tais relações são reconhecidas como desfavoráveis, já que prescinde de uma elevação livre e consciente acima da vontade e do conhecimento a ela referido.

As experiências que o sublime nos traz são mais perturbadoras, já o belo representa-nos apenas a imagem do bem. O sublime nos traz a ideia de infinito e também a de liberdade, e esta tem que ser total. "O belo está ligado à concordância de nossas faculdades, o sublime a seu conflito" (JIMENEZ, 1999, p. 144).

O Belo é harmônico, o Sublime pode ser disforme, informe, caótico. Prazer para um, dor e prazer para o outro. Para o autor, os ajuizamentos podem estar ligados mais a um prazer do que a um conhecimento do objeto em si, já o belo sempre está relacionado ao objeto sensível, enquanto o sublime é semelhante à conceito de belo e sublime estendendo-se a arte contemporânea. Revista da FUNDARTE. Montenegro, p.01-21, ano 20, no 41, Abril/Junho de 2019.

Disponível em: http://.seer.fundarte.rs.gov.br/index.php/RevistadaFundarte/index> 30 de junho de 2020 


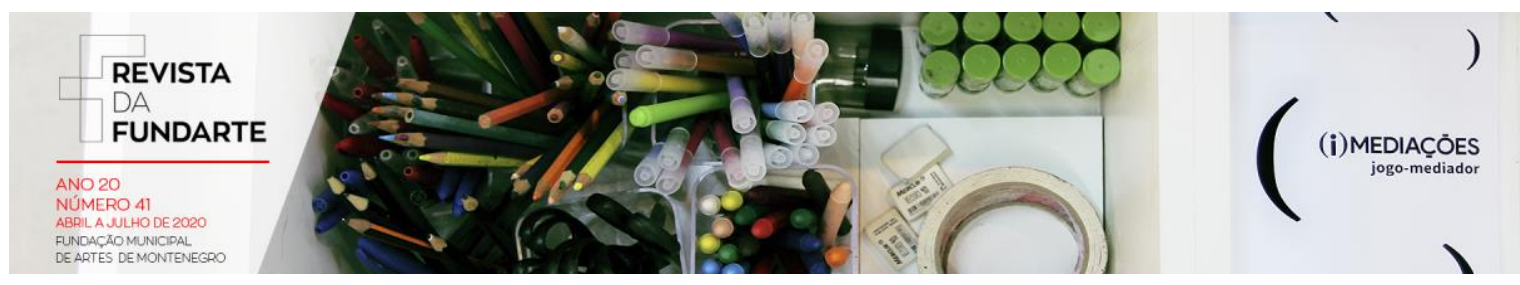

razão. "O Sublime distingue-se do Belo pelo fato de provocar perturbações filosóficas ligadas a uma mistura de dor e prazer" (JIMENEZ, 1999, p. 136).

Desse modo, é importante frisar que muito se discute o conceito de Belo na Arte, cuja apreciação prescinde da ideia de Belo universal, ou seja, pressupõe um acordo entre o artista e o expectador, no qual o artista procura estabelecer uma harmonia entre a imaginação e a compreensão. É o que Deleuze chama de juízo de gosto, que exprime no expectador um acordo, uma harmonia de duas faculdades: imaginação e entendimento. Se o juízo de gosto se distingue do juízo de preferência é porque ele prescinde uma certa necessidade, uma certa universalidade a priori. Para o autor, ele toma do entendimento, portanto, sua legalidade, mas esta legalidade não aparece aqui em conceitos determinados. "A universalidade no juízo de gosto é aquela de um prazer; a coisa é singular, e permanece sem conceito" (DELEUZE, 1963, p. 2).

Dessa forma, a ideia do entendimento está implícita, uma vez que a imaginação busca um sentido que guiará o juízo estético. Para Deleuze (1963), o juízo estético está comprometido com a ideia do belo universal, pois ela remete ao conceito que o artista busca representar. $O$ autor chama de esquematismo 0 ato original da imaginação, relacionado a um conceito determinado do entendimento. Ele continua afirmando que sem conceito do entendimento, a imaginação faz outra coisa, ao invés de esquematizar. Ela reflete. "É este o verdadeiro papel da imaginação no juízo estético: ela reflete a forma do objeto. Por forma, aqui, não se deve entender forma da intuição (sensibilidade) " (DELEUZE, 1963, p. 6).

Deleuze (1963) afirma que a arte auxilia o homem a superar o objeto do desejo, na medida em que o conduz a outras esferas do espírito, que o eleva do plano puramente material, físico palpável, para outro, diverso e acima deste, cuja inclinação sensorial é manifesta, o eleva ao plano suprassensível. O sublime, por outro lado, coloca-nos, pois, na presença de uma relação subjetiva direta entre a imaginação e a razão. conceito de belo e sublime estendendo-se a arte contemporânea. Revista da FUNDARTE. Montenegro, p.01-21, ano 20, no 41, Abril/Junho de 2019.

Disponível em: http://.seer.fundarte.rs.gov.br/index.php/RevistadaFundarte/index> 30 de junho de 2020 


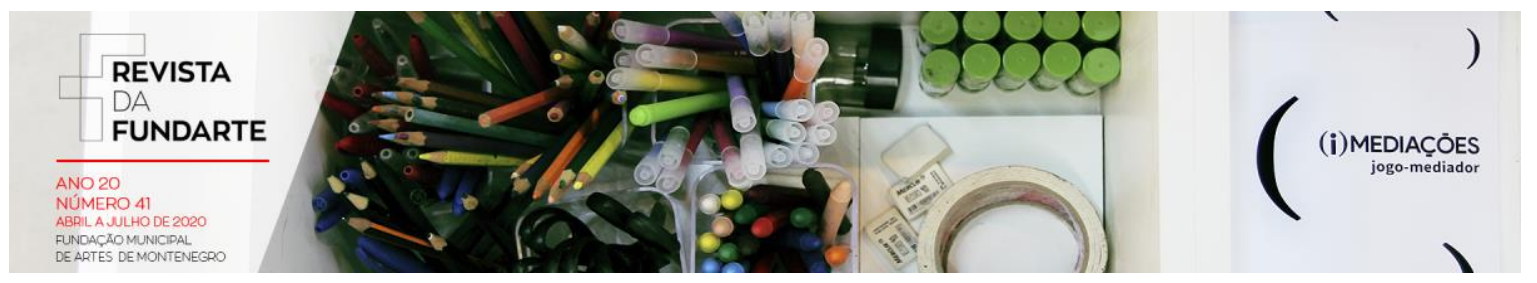

O autor observa que é mais do que um acordo, esta relação é em primeiro lugar um desacordo, uma contradição vivida entre a exigência da razão e a potência da imaginação. "É por isso que a imaginação parece perder a sua liberdade e o sentimento do sublime, uma dor mais do que o prazer" (DELEUZE, 1963, p. 58). Porém, ele ressalta que no fundo do desacordo surge o acordo; a dor torna possível um prazer. Quando a imaginação é posta na presença do seu limite por alguma coisa que a supera por todos os lados, ela mesma supera o seu próprio limite de maneira negativa, representando a inacessibilidade da Ideia racional e fazendo dessa própria inacessibilidade algo de presente na natureza sensível. Ele complementa,

[...] tal é o acordo-discordante-da imaginação e da razão: não é apenas a razão que tem uma distinção "supra-sensível", mas também a imaginação. Nesse acordo a alma é sentida como a unidade supra-sensível indeterminada de todas as faculdades; somos nós próprios referidos a um foco, como a um "ponto de concentração" no suprassensível. (DELEUZE, 1963, p. 58).

Desse modo, o Sublime, a partir da apreciação de uma obra de arte, seria um "estado de êxtase", cuja sensação é resultado do prazer que surge e é produzido pelos sentidos, impulsionado por um acontecimento momentâneo, seguido de uma efusão sensorial, que por ser emoção, se expressa como um prazer extremo, na relação entre razão e imaginação.

\section{RELEXÕES FINAIS}

Para auxiliar a reflexão pretendida e objeto deste texto sobre os conceitos de Belo e Sublime, partiu-se da concepção grega de Belo, cuja ideia deveria responder a três critérios: ordem, simetria e proporção. Com o passar do tempo, a palavra Belo passa a expressar algo que agrada, que provoca admiração e que atrai o olhar.

HUMMES, Julia Maria; DAL BELLO, Márcia Pessoa; DAL BELLO, Ubyrajara. Relexões sobre o conceito de belo e sublime estendendo-se a arte contemporânea. Revista da FUNDARTE. Montenegro, p.01-21, ano 20, no 41, Abril/Junho de 2019.

Disponível em: http://.seer.fundarte.rs.gov.br/index.php/RevistadaFundarte/index> 30 de junho de 2020 


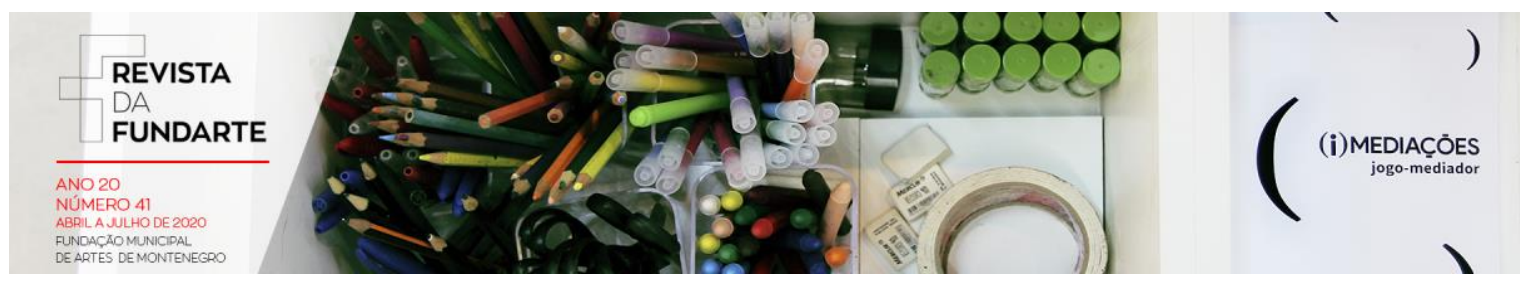

$\mathrm{Na}$ medida que a sociedade grega vai se transformando, a arte amplia as suas dimensões e, a palavra Belo já não dá mais conta de explicar o que transcende a apreciação da obra. Assim, no final do século XVIII, em pleno romantismo, o uso do termo Sublime começa a ser utilizado para expressar o sentido implícito na obra, cujo significado da palavra expressava "aquele ou aquilo que se eleva", "aquele ou aquilo que se sustenta no ar", que provoca o afloramento da sensibilidade.

No intuito de aprofundar a discussão sobre os conceitos de Belo e Sublime, na apreciação da obra de Arte, foi inevitável que se promovesse uma interlocução com vários autores estudiosos sobre os temas em questão, cujos pensamentos convergiram para a ideia de que, tanto o Belo como o Sublime transitam pela sensibilidade humana, a partir da observação da obra e das sensações que a sua apreciação provoca no expectador.

Enquanto o Belo leva a um entendimento ilimitado, o Sublime conduz à razão pura, o que significa a totalidade da compreensão. O Belo encanta pela simplicidade, agrada, pois, os sentidos. A impressão deixada no indivíduo, na contemplação de uma obra Sublime, por sua vez, pode estar representada pelo terror, pela desolação, pelos sentimentos desagradáveis, mas também pelos agradáveis, podendo surpreender pelo esplendor, pelo encanto ou por estranhamento. Enquanto o Belo é tranquilizador, o Sublime é inquietante.

Seguindo as considerações relatadas no texto podemos dizer que o Sublime se distingue do Belo por provocar sentimentos perturbadores, tanto na dimensão do prazer como da dor. O Belo é mais ameno, dá uma dimensão de prazer mais serena e menos impactante.

É possível encontrar um exemplo concreto na bela arquitetura da Grécia antiga que traz detalhes refinados, muita beleza e harmonia nas formas. Nestas obras arquitetônicas encontramos a perfeição do retrato humano (Figura 1), a beleza nos altares e nas colunas (Figura 2), sempre buscando na matemática a perfeição visual. $\mathrm{O}$ que contrasta com a sublime arquitetura Gótica que apresenta detalhes, conceito de belo e sublime estendendo-se a arte contemporânea. Revista da FUNDARTE. Montenegro, p.01-21, ano 20, no 41, Abril/Junho de 2019.

Disponível em: http://.seer.fundarte.rs.gov.br/index.php/RevistadaFundarte/index> 30 de junho de 2020 


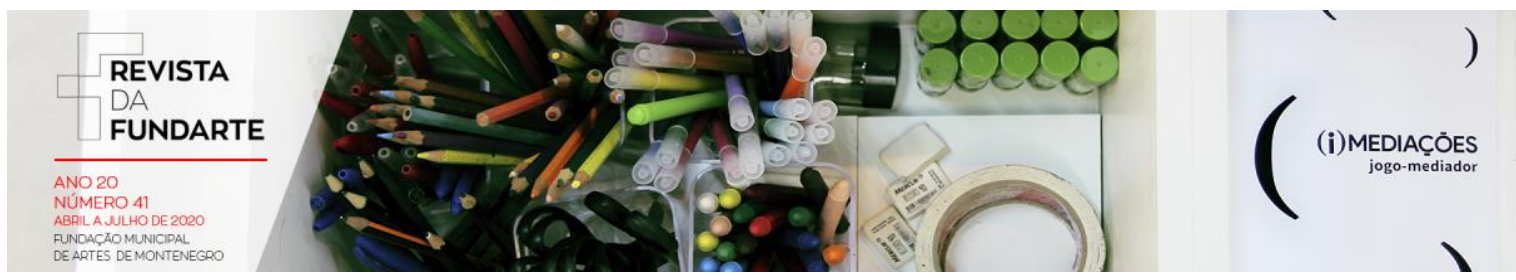

um grande porte, planta em formato de cruz, grandes torres com gárgulas esculpidas, impondo uma plenitude muitas vezes assustadora.

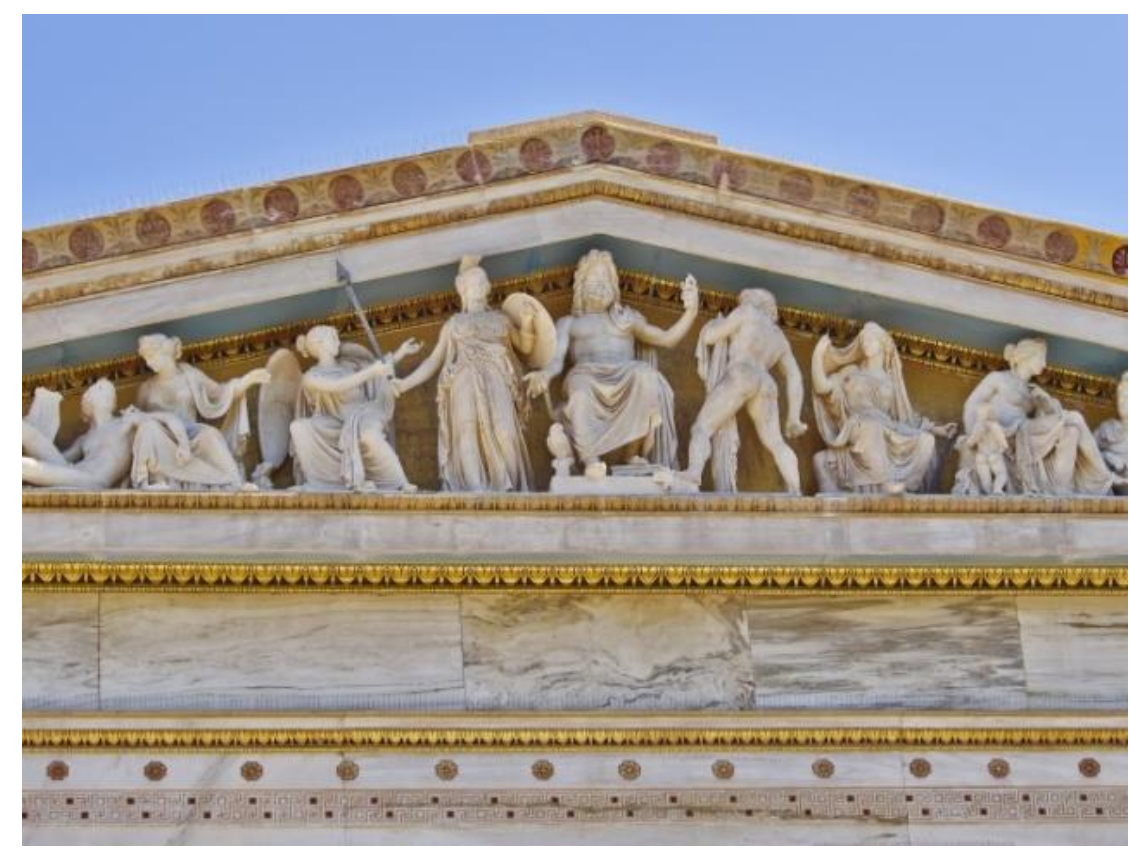

Figura 1 - representação do homem na Grécia Antiga

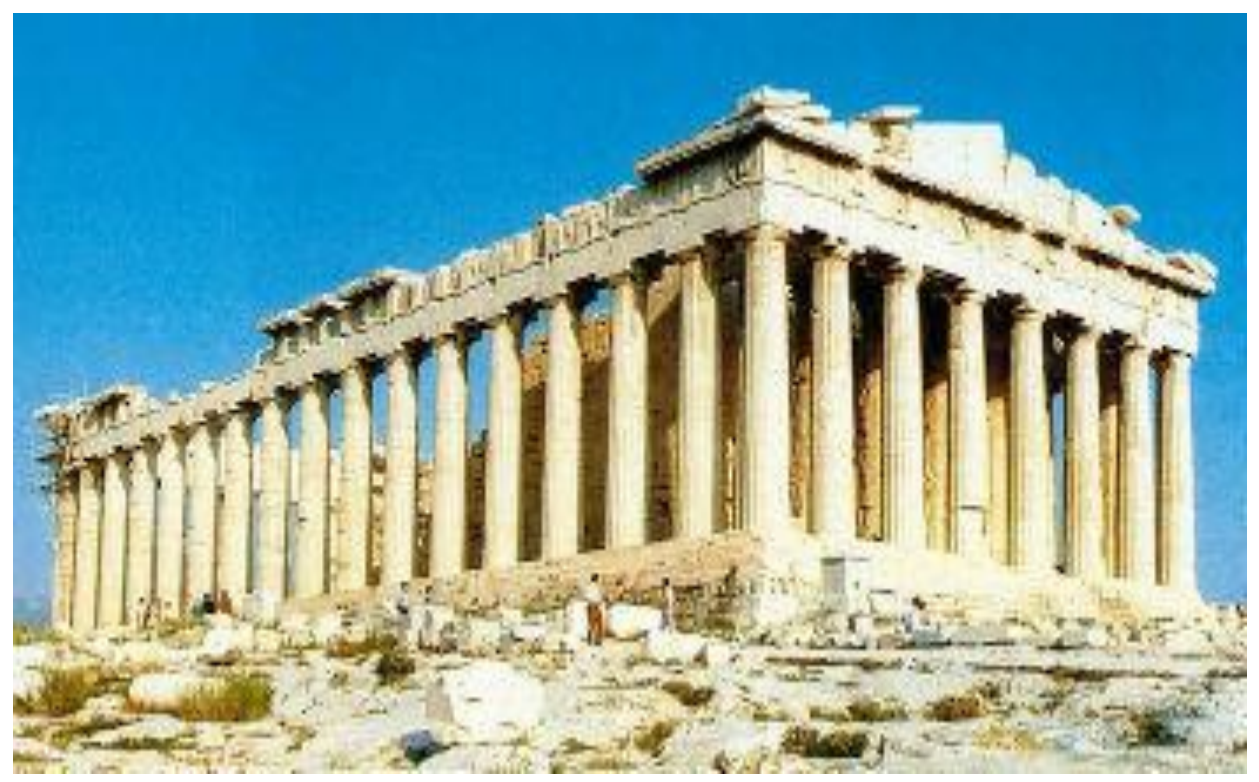

Figura 2 - colunas utilizadas na Grécia Antiga

HUMMES, Julia Maria; DAL BELLO, Márcia Pessoa; DAL BELLO, Ubyrajara. Relexões sobre o conceito de belo e sublime estendendo-se a arte contemporânea. Revista da FUNDARTE. Montenegro, p.01-21, ano 20, oㅜ 41, Abril/Junho de 2019.

Disponível em: http://.seer.fundarte.rs.gov.br/index.php/RevistadaFundarte/index> 30 de junho de 2020 


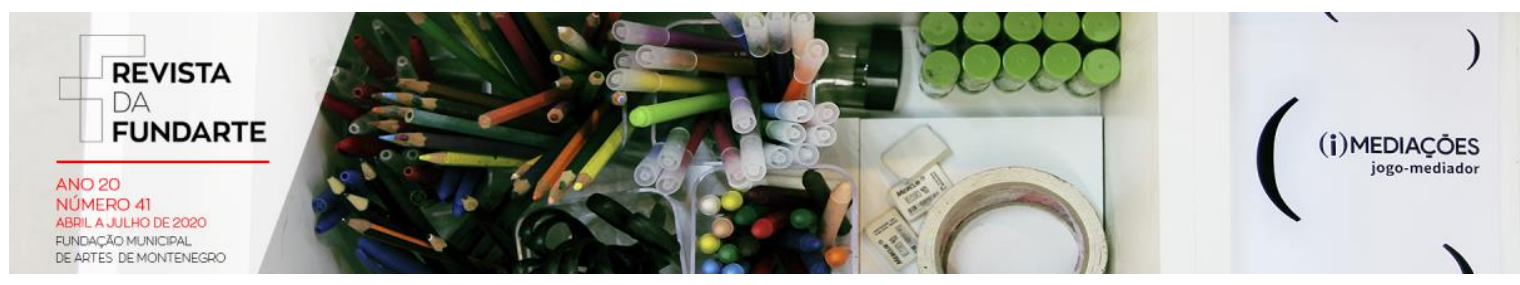

Pode-se comparar também um belo concerto grosso barroco ${ }^{5}$ a uma sublime Ópera de Wagner ${ }^{6}$. Fica claro que a diferença de prazer, de impacto, de dramaticidade ou de perturbação do ouvinte diante de cada obra a coloca no devido patamar de satisfação.

A diferença entre o Belo e o Sublime se coloca bem evidente nas artes visuais, como por exemplo quando comparamos uma obra de John Constable a uma de William Turner. Vejamos os exemplos The Hay Wain - John Constable e El naufrágio de William Turner, na figura 3. Pode-se dizer que o Belo traz o simples prazer da contemplação, mostra uma natureza como espaço acolhedor que convida, de certa forma, a participar. Já na figura 4, o Sublime traz uma sensação de admiração, se somando a vários sentimentos que ultrapassam o simples prazer, mostrando uma natureza indomável, rebelde.

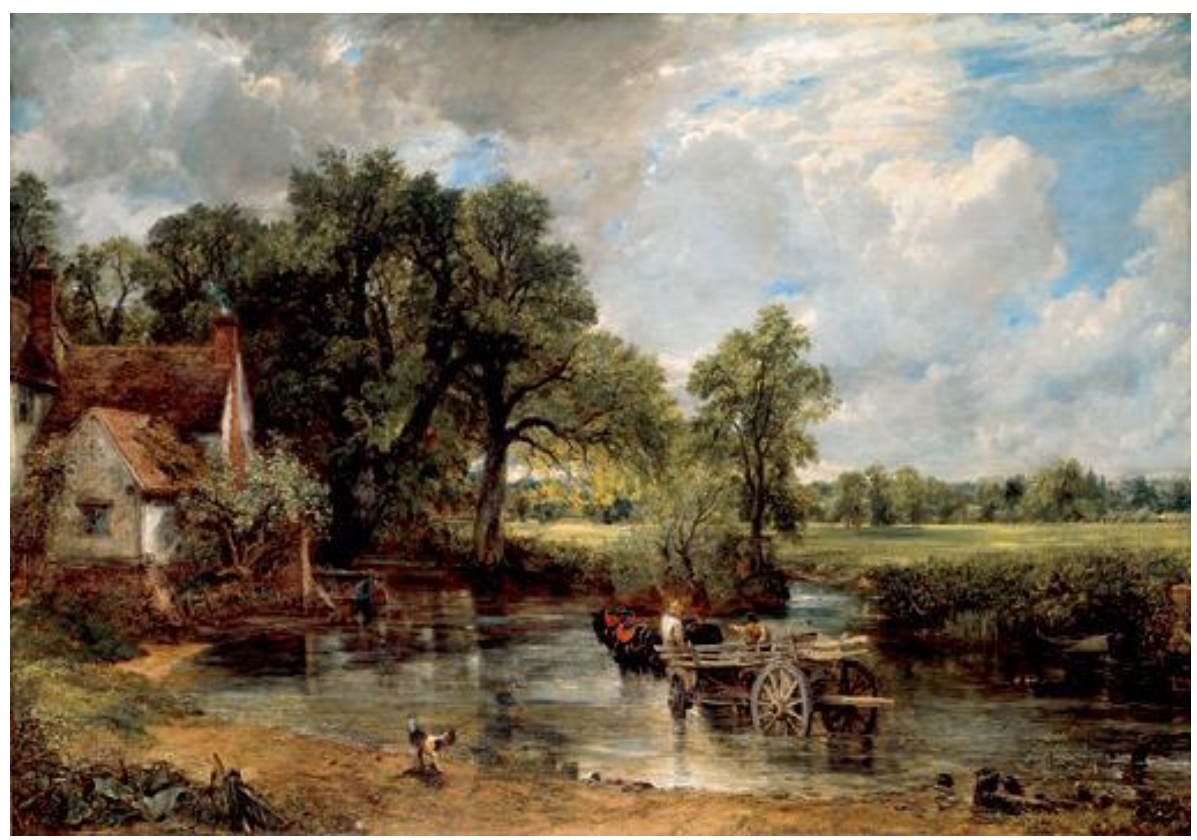

Figura 3 - The Hay Wain - John Constable

\begin{abstract}
${ }^{5} \mathrm{~A}$ forma instrumental "concerto grosso" surgiu no final do século XVII, é um concerto onde um grupo de solistas (normalmente de cordas) também conhecidos como concertinho, dialoga com o restante da orquestra, também conhecida como "tutti".

${ }^{6}$ As óperas de Richard Wagner são conhecidas pela dramaticidade musical, com texturas bastante complexas, orquestração ousada e harmonias interessantes.
\end{abstract}

HUMMES, Julia Maria; DAL BELLO, Márcia Pessoa; DAL BELLO, Ubyrajara. Relexões sobre o conceito de belo e sublime estendendo-se a arte contemporânea. Revista da FUNDARTE. Montenegro, p.01-21, ano 20, oㅡ 41, Abril/Junho de 2019.

Disponível em: http://.seer.fundarte.rs.gov.br/index.php/RevistadaFundarte/index> 30 de junho de 2020 

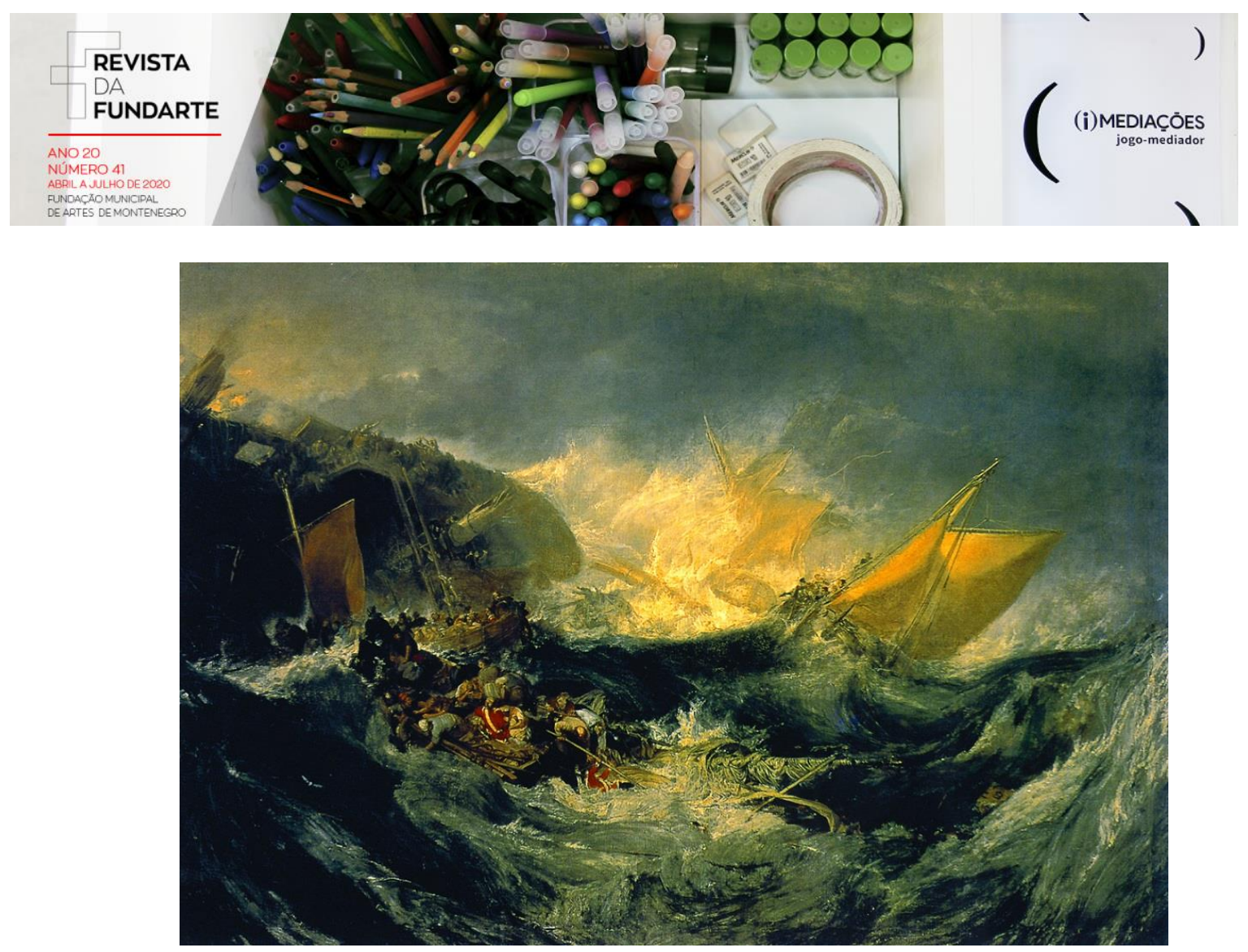

Figura 4 - El naufrágio de William Turner

Certamente todo artista, ao conceber sua obra, busca uma satisfação pessoal, mas também espera uma resposta do observador, ou seja, a sua expectativa será tocar o espectador. É evidente que a obra ser considerada Sublime por quem a olha é uma aspiração para poucos, entretanto a sua apreciação estética também é diversa e singular. Uma mesma obra pode ser apreciada por muitos que poderão julgá-la como bela ou sublime, entretanto outros tantos poderão considerála inexpressiva. É importante observar que, dependendo da complexidade da obra, algumas provocam uma leitura imediata, onde o Belo ou o Sublime se impõem, entretanto outras necessitam de um tempo maior, para que a sua apreciação chegue ao alcance do espectador.

Um exemplo de uma obra contemporânea que suscita outras sensações é "Einstein on the beach"- Einstein na Praia. Este título pode parecer, num primeiro momento, uma estratégia de marketing, onde a busca pelo leitor curioso que ao imaginar Einstein na praia, logo se remete a loucuras, pesquisa e curiosidade. conceito de belo e sublime estendendo-se a arte contemporânea. Revista da FUNDARTE. Montenegro, p.01-21, ano 20, oㅡ 41, Abril/Junho de 2019.

Disponível em: http://.seer.fundarte.rs.gov.br/index.php/RevistadaFundarte/index> 30 de junho de 2020 


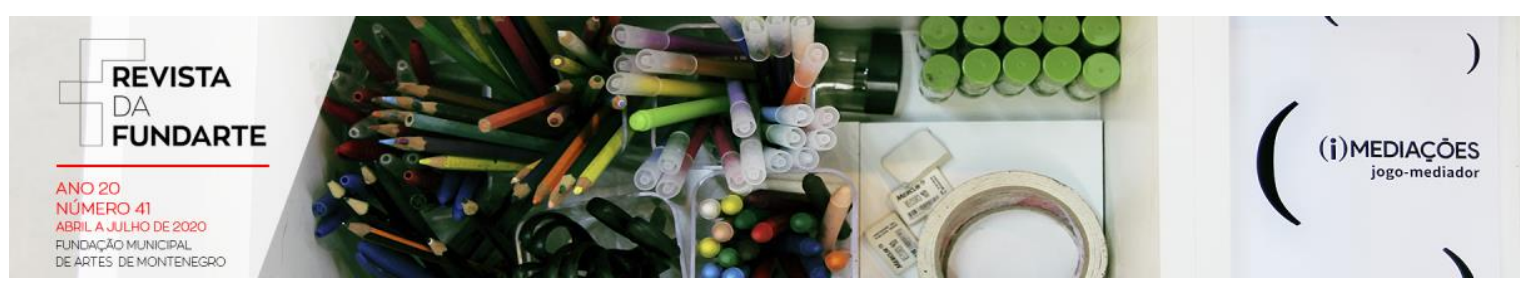

$\mathrm{Na}$ verdade este é o título de uma obra musical, mais especificamente uma Ópera criada pelos compositores Robert Wilson e Philip Glass no ano de 1975. É sim uma obra muito curiosa, estruturada em 4 atos, ligados por 5 intermezzos.

Apesar da forma rígida, tem total liberdade de interpretação, utilizando elementos não harmônicos, mas muito expressivos que levam o ouvinte à ambientes ainda não visitados, num movimento circular de sons extraordinários e não previsíveis. É uma obra do universo da música contemporânea.

A ópera é minimalista e tem a duração de 5 horas. Imaginem que provavelmente é bastante monótona. A obra possui frases curtas ou pequenos motivos que se repetem por muito tempo e muitas vezes tornando a música repetitiva demais. A plateia tem a liberdade de entrar e sair no momento que julgar adequado. A ideia é provocar nesta plateia uma espécie de "hipnose", estado de transe, superconcentração, meditação, sempre na busca pelo entendimento. É mais sensorial do que deleite.

São desafios que os compositores lançam aos ouvintes, que muitas vezes buscam entender suas obras ou apenas apreciá-las. Gostar ou não gostar?

Outro exemplo a ser citado se trata de uma obra contemporânea, a instalação da Artista Úrsula Jahn (Figura 5). Nesta obra a artista relata:

$\mathrm{Na}$ exposição, apresentei essas tábuas sobre uma grande mesa e, mesclando com as obras, preenchendo os espaços vazios, adicionei alimentos da cor vermelha, como tomates, pimentões, pimentas e maçãs, com a intenção de fortalecer minha proposta. Criar efetivamente esse banquete. $\mathrm{O}$ uso dos alimentos vermelhos se deu pela associação a uma cor provocativa, a fim de questionar também essa noção de corpo como algo tentador e também por vermelho ser associado a sangue, enfatizando as feridas e consequências que uma cultura machista pode acabar ocasionando para a mulher. (JAHN, 2019).

HUMMES, Julia Maria; DAL BELLO, Márcia Pessoa; DAL BELLO, Ubyrajara. Relexões sobre o conceito de belo e sublime estendendo-se a arte contemporânea. Revista da FUNDARTE. Montenegro, p.01-21, ano 20, no 41, Abril/Junho de 2019.

Disponível em: http://.seer.fundarte.rs.gov.br/index.php/RevistadaFundarte/index> 30 de junho de 2020 

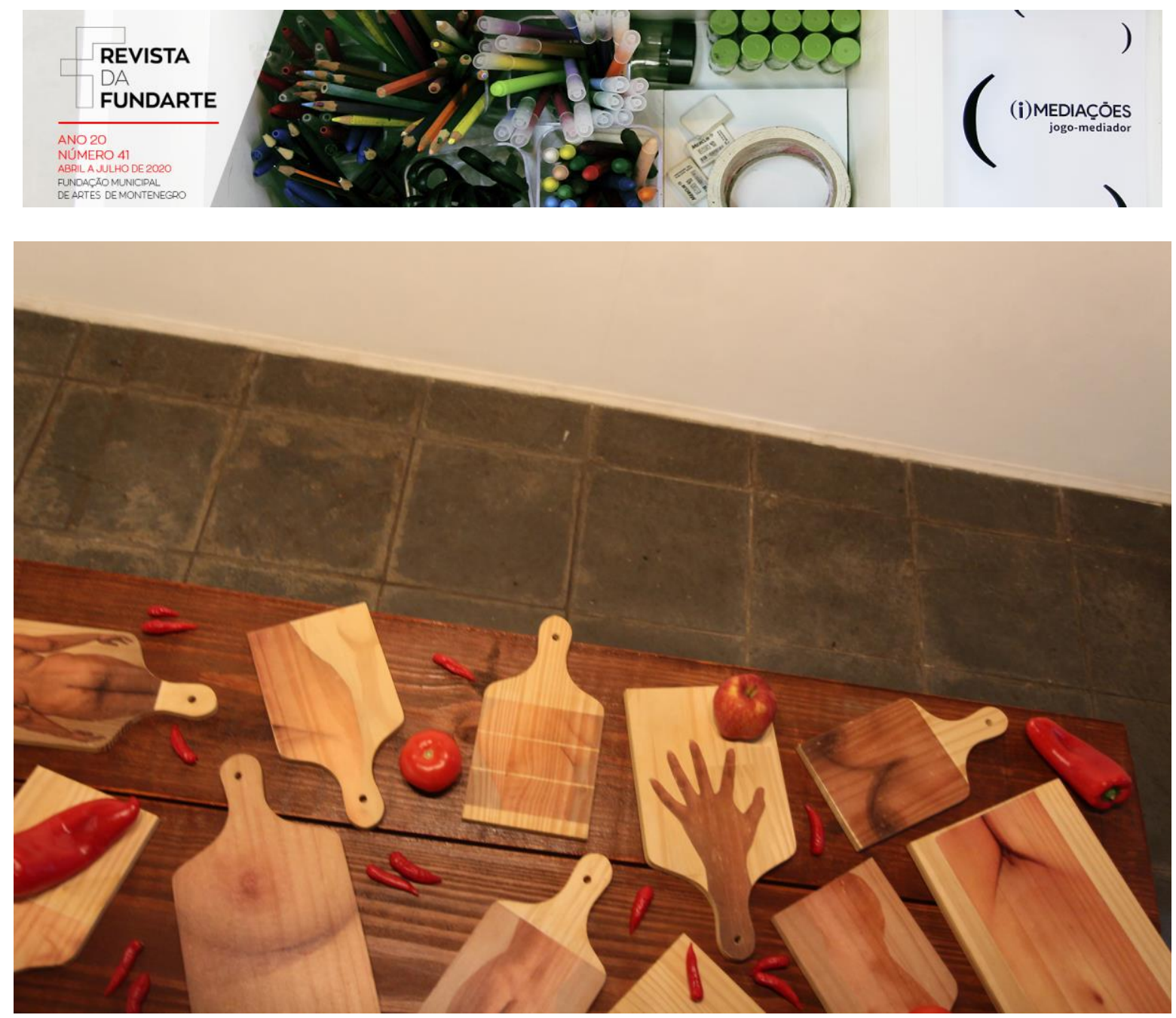

Fig. 5 - À la carte (2016) - Mostra Através da Imagem - ano cinco, ao lado das artistas Bruna Engel e Mariane Rotter, também curadora da exposição, na Galeria Loide Schwambach na Fundação de Artes de Montenegro em agosto de 2019. (Foto de Estevão Dornelles)

Segundo a autora, na instalação À la carte (2016) é possível ver a conexão do feminino com a mercadoria. O trabalho é composto de imagens do corpo feminino que foram transferidas para tábuas de carne, e propõem um questionamento sobre a concepção do corpo feminino como um objeto de consumo. Ela ainda diz

[...]busco transmitir uma mensagem direta: a coisificação da mulher e a sensação de se ser um pedaço de carne, exposto para livre apreciação e escolha. Ao optar por deslocar a imagem fotográfica bidimensional para um objeto fotográfico, a tábua de madeira, quis que o próprio suporte se inserisse como crítica. (JAHN, 2019).

A Instalação de Úrsula vem ao encontro de várias características da arte contemporânea que valoriza outros conceitos, estimulando o desejo inerente do ser humano pelas invenções e experimentações artísticas. Alguns das principais

HUMMES, Julia Maria; DAL BELLO, Márcia Pessoa; DAL BELLO, Ubyrajara. Relexões sobre o conceito de belo e sublime estendendo-se a arte contemporânea. Revista da FUNDARTE. Montenegro, p.01-21, ano 20, no 41, Abril/Junho de 2019.

Disponível em: http://.seer.fundarte.rs.gov.br/index.php/RevistadaFundarte/index> 30 de junho de 2020 


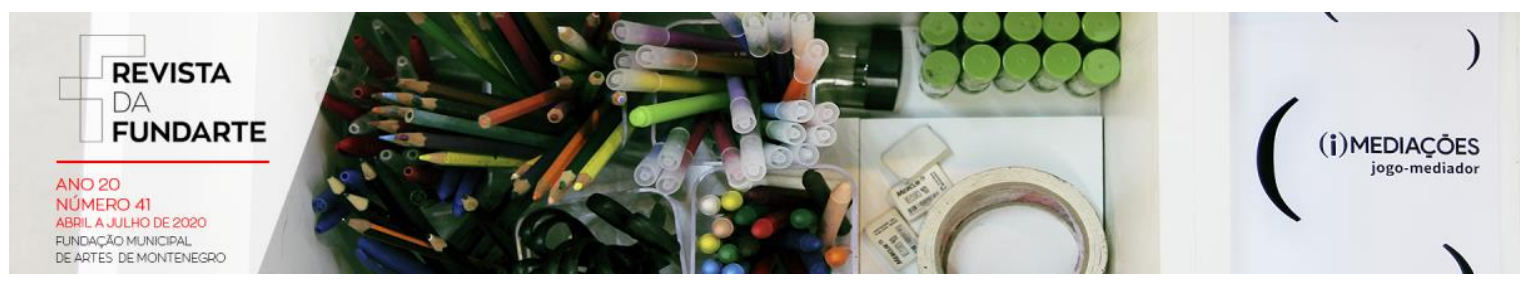

características da arte contemporânea são o abandono dos suportes tradicionais; a fusão entre arte e vida; o uso das novas tecnologias e mídias; a mistura de estilos artísticos; obras interativas; obras questionam a definição de arte; a aproximação com a cultura popular; o uso de diferentes materiais para a produção das obras; a liberdade e efemeridade artística; conceitos baseados em informação da sociedade,( www.significados.com.br/arte-contemporanea).

Para finalizar, parece pertinente chamar atenção, ainda, para o fato de que, assim como a designação do "Belo" não deu conta de expressar o sentido e a emoção presentes na obra de arte na antiguidade, no momento atual, as obras produzidas na contemporaneidade, igualmente, prescindem de outros adjetivos, para expressá-las em todo o seu esplendor conceitual.

\section{Referências:}

BELLAS, João Pedro. O Romantismo e o Sublime. Anais do VII Seminário dos Alunos dos Programas de Pós-Graduação do Instituto de Letras da UFF Estudos de Literatura Anais do VII SAPPIL - Estudos de Literatura, UFF, no 1, 2016. [271]

BURKE, Edmund. A Philosophical Enquiry in to the Origins o four Ideas of the Sublime and Beautful. Ed Adam Philips. New York: Oxford, 2008.

DELEUZE, Giles. A filosofia crítica de Kant. Tradução de Geminiano Franco. Lisboa/Portugal. Edição 70. 1963.

ECO, Umberto. História da Beleza. Trad. Eliana Aguiar. 4aㅗ edição. Rio de Janeiro: Record, 2014.

JAHN, Úrsula. Através da imagem. Revista da FUNDARTE, Montenegro: Editora da FUNDARTE, no 39, julho/dezembro de 2019.

JIMENEZ, Marc. O que é estética? Tradução de Fulvia M. L. Moretto. São Leopoldo: Unisinos, 1999.

KANT, Immanuel. Anthropology from a pragmatic point of view. Carbondale: Southern Illinois University Press, 1978. 


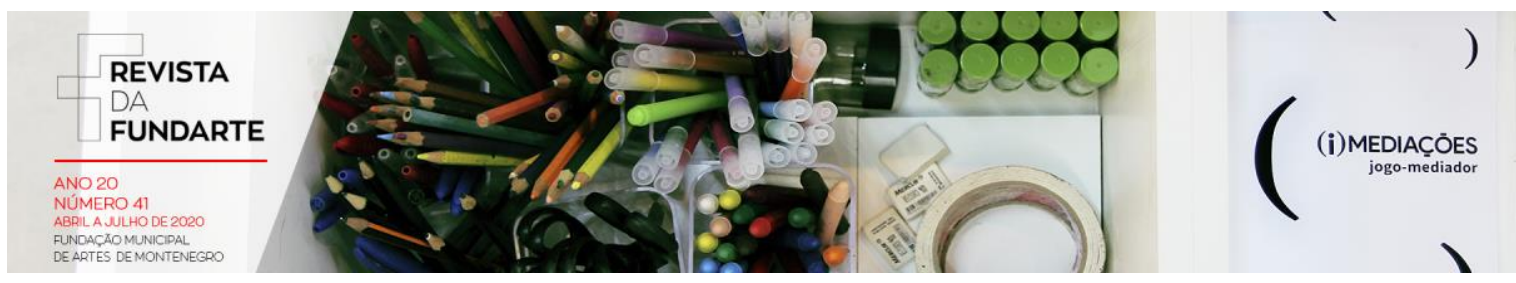

Observações sobre o sentimento do belo e do sublime. 2. ed. Campinas, Trad. De Vinícius Figueiredo. São Paulo: Papirus Editora, 1993.

. Crítica da faculdade do juízo. Tradução de Valério Rohden e Antônio Marques. 2. ed. Rio de Janeiro: Forense Universitária, 1995.

Crítica da Faculdade do Juízo. 2. ed. Trad. De Valério Rohden e António Marques. Rio de Janeiro: Editora Forense Universitária, 2005.

Antropologia de um ponto de vista pragmático. Trad. Clélia Aparecida Martins, São Paulo: Iluminuras, 2006.

LINO, Alice de Carvalho. A relação dos conceitos do belo e do sublime na representação dos gêneros. Universidade de São Paulo. Kant e-Prints. Campinas, Série 2, v. 3, n. 1, p. 27-39, jan.-jun., 2008.

REALE, Giovanni; ANTISERI, Dario. História da Filosofia: de Spinoza a Kant. Tradução de Ivo Stomiolo. V. 4. São Paulo: Paulus, 2005.

RHODEN, Valério (org). 200 Anos da Crítica da Faculdade do Juízo de Kant, 1790 1990. Porto Alegre: Ed. Da Universidade/UFRGS, Instituto Goethe/ICBA, 1992.

SCHOPENHAUER, Arthur. Metafísica do Belo. Trad. Jair Barbosa. São Paulo: Editora UNESP, 2003.

SILVEIRA, Carlos Roberto da; RIBEIRO, Alan Barcelos. O pensamento filosófico de Schopenhauer sobre a música e suas possíveis contribuições para a educação musical brasileira - Theoria - Revista Eletrônica de Filosofia Faculdade Católica de Pouso Alegre. Volume 04 - Número 09 - Ano 2012.

SILVA, Hélio Lopes. A Imaginação na crítica kantiana dos juízos estéticos. Artefilosofia. Ouro Preto, vol.1, n.1, p. 45-55, jul. 2006.

\section{Referências eletrônicas:}

http://revistaseletronicas.pucrs.br/ojs/index.php/intuitio/article/view/18840

http://revistaentelekheia.blogspot.com.br/2008/08/o-belo-e-o-sublime-arthur-

schopenhauer.html.

http://revistaentelekheia.blogspot.com.br/2008/08/o-belo-e-o-sublime-arthur-

schopenhauer.html

https://pt.wikipedia.org/wiki/Romantismo

https://pt.wikipedia.org/wiki/Sublime (est\%C3\%A9tica)

https://www.significados.com.br/arte-contemporanea/

http://.seer.fundarte.rs.gov.br/index.php/RevistadaFundarte/2019.

HUMMES, Julia Maria; DAL BELLO, Márcia Pessoa; DAL BELLO, Ubyrajara. Relexões sobre o conceito de belo e sublime estendendo-se a arte contemporânea. Revista da FUNDARTE. Montenegro, p.01-21, ano 20, nำ41, Abril/Junho de 2019.

Disponível em: http://.seer.fundarte.rs.gov.br/index.php/RevistadaFundarte/index> 30 de junho de 2020 